\title{
Institutionella villkor för mediehantering - en jämförande kartläggning mellan socialtjänst, skola och polis
}

\section{JESPER ENBOM, STEFAN SJÖSTRÖM \& ADAM ÖHMAN}

För offentliga organisationer kan mediers granskning uppfattas som problematisk. Representanter för socialtjänstorganisationer har i flera uppmärksammade fall framstått som handfallna när de konfronterats med medier. Under senare år har offentliga organisationer kommit att utveckla mer professionella mediestrategier. Artikeln rapporterar resultat från en nationellt representativ enkät om mediehantering inom socialtjänst, skola och polis.

\section{Inledning}

På senare år har organisationer inom offentlig sektor alltmer kommit att intressera sig för hur de uppfattas av allmänheten (Larsson, 2005). Detta kan ses

Jesper Enbom, FD, universitetslektor i medie- och kommunikationsvetenskap, Umeå universitet. Stefan Sjöström, FD, docent i socialt arbete, Umeå universitet.

Adam Öhman, doktorand i medie- och kommunikationsvetenskap, Umeå universitet. som uttryck för dels den tilltagande medialiseringen av samhället (Schillemans, 2012), dels den tilltagande granskningen av offentlig verksamhet (Power, 2007). Rothstein et al (2006) pekar på risken att en alltför stor upptagenhet vid extern granskning kan leda till att myndigheter blir mer angelägna om hur de framstår än av kvaliteten på verksamheten. Ett ytterligare förhållande som förändrar offentliga organisationers förhållningssätt till allmänheten är att de i allt större utsträck- 
ning agerar i konkurrens med privata aktörer. Detta leder till ökat fokus på marknadsföring och varumärkesvård.

Mot bakgrund av medialisering, konkurrensutsättning och utveckling mot ett granskningssamhälle blir frågan om hur man framställs i massmedier allt viktigare för offentliga organisationer. Professionell mediehantering får därmed ökad betydelse (Larsson, 2005). Inom den privata sektorn är mediehantering ett etablerat verktyg som ytterst syftar mot vinstmaximering (Ewen, 1996; Wernick, 1991). Här finns en fundamental skillnad mot offentliga organisationer. Visserligen kan dessa sägas ha egenintressen i form av exempelvis fortsatta budgettillskott. Men primärt är tanken att de ska styras utifrån demokratiska principer och värden som överskrider organisatoriska egenintressen (jfr Schillemans, 2012). Därför blir målen för offentliga organisationers mediehantering annorlunda än för privata företag. Medborgarna har rätt att förvänta sig att dessa på ett rättvisande sätt kommunicerar hur de politiska målen uppfylls och att de inte skyler över brister.

Villkoren för mediehantering varierar mellan olika typer av offentliga organisationer. I artikeln analyseras detta med avseende på socialtjänst, skola och polis. Dessa verksamheter agerar utifrån olika ramverk och ställs därför inför olika typer av utmaningar $\mathrm{i}$ fråga om mediehantering. Socialförvaltningar kan till exempel bli föremål för intensiva granskningar i enskilda fall där de på grund av sekretessregler begränsas i vilka förklaringar de kan göra till sitt agerande (Forsberg, 2011; Franklin \& Parton, 1991). För polisen är massmedier ofta en viktig resurs för att få hjälp av allmänheten med pågående brottsundersökningar (Chermak \& Weiss, 2005). Kommunala skolor är i hög grad konkurrensutsatta och behöver därför framställa sig som attraktiva på en marknad (Lundström \& Holm, 2011).

I dagsläget är forskningen om mediehantering $\mathrm{i}$ offentlig sektor ytterst begränsad (Schillemans 2012; Thorbjørnsrud et al., 2014). Inom ramen för ett större forskningsprojekt ${ }^{1}$ presenterar vi här empiriska data från en nationellt representativ enkätundersökning. Syftet med studien har varit att kartlägga och jämföra hur mediehanteringen organiseras inom socialtjänst, skola och polis. Detta studeras med avseende på policy, personal och aktiviteter. Vi diskuterar möjligheten att tolka de skillnader som identifieras utifrån en modell för olika institutionella villkor för mediehantering som vi skapat. Mediehantering definieras i denna studie som aktiviteter riktade mot nyhetsredaktioner med syfte att förebygga negativ och stimulera till positiv publicitet.

\section{Tidigare forskning}

Under de senaste två decennierna har det vuxit fram en omfattande litteratur som behandlar hur organisationer arbetar med mediehantering. Studierna har visat hur mediehanteringen professionaliserats och har dessutom identifierat strategier som används för att uppnå gynnsam

1 Mellan organisationsintresse och demokratiskt uppdrag. Utmaningar inom mediehantering inom polis, socialtjänst och skola. Vetenskapsrådet dnr 421-2011-2172. 
publicitet. Kearns (2003) skiljer mellan reaktiva och proaktiva strategier, där de förstnämnda handlar om att snabbt och adekvat reagera på kritik, medan de andra innebär att påverka dagordningen i den offentliga debatten. När det gäller proaktiva strategier har forskare identifierat sådant som etablering av kontaktnät med journalister, spridning av exklusiva uppgifter och medieträning (Allern, 1997; Enbom, 2009). En särskilt viktig strategi är anpassning till journalistikens kriterier för nyhetsvärdering. Sådana kriterier leder journalister mot att bland annat personifiera en nyhetsberättelse, rapportera om händelser som ligger geografiskt nära, samt fokusera på dramatiska aspekter (Altheide \& Snow, 1979; Galtung \& Ruge, 1981; Strömbäck, 2008). Reaktiva mediestrategier handlar om att reagera när någon annan initierat frågor som berör den egna organisationen. Detta handlar ofta om att motverka negativ publicitet i samband med massmedial granskning, exempelvis genom att förminska betydelsen av händelser som kritiserats (Benoit, 1997; Coombs, 2007).

Schillemans (2012) har undersökt offentliga organisationers mediehantering som uttryck för medialisering. De organisationer han studerat arbetar i stor utsträckning med systematisk mediebevakning och är i hög grad upptagna av att nå publicitet $\mathrm{i}$ vissa fall och undvika den i andra. Ihlen och Thorbjørnsrud (2014) har studerat myndigheters strategier för att hantera kritik i massmedier som appellerar till känslor. De finner att organisationerna lägger ner avsevärda resurser för att hantera sådan kritik. Samtidigt känner byråkrater en påtaglig tveksamhet inför att tillämpa professionella mediestrategier då dessa kan leda till förenkling och brist på nyansering.

Den internationella forskningen om medieskildringar av och mediehantering inom socialtjänst, skola och polis är begränsad. Det förekommer enstaka studier om socialarbetares upplevelser av medierapportering (Andersson \& Lundström 2004; Brunnberg 2001), men det finns oss veterligen inte någon empirisk forskning som närmare undersöker hur vare sig socialtjänstorganisationer eller skolväsendet arbetar med mediehantering. Det finns dock en tämligen extensiv forskning om relationen mellan polisen och nyhetsmedier i en anglosaxisk kontext.

En återkommande iakttagelse i den internationella forskningen om socialarbetare $\mathrm{i}$ medier är att de tenderar att beskrivas som antingen "wimps", som inte tar tag i problem, eller "bullies", som på lösa grunder griper in och tvångsomhändertar barn (Franklin, 1989). Ayre (2001) pekar på att massmediebevakningen haft en direkt effekt på den sociala barnavårdens praktik i England. Särskilt betydelsefulla har så kallade "celebrated child abuse scandals" varit. Aldridge (1990) har framhållit mediernas benägenhet att förenkla som ett av de centrala problemen utifrån ett socialarbetarperspektiv.

Med utgångspunkt i egna reflektioner och enstaka berättelser från praktiker, diskuterar Reid och Misener (2001) och Franklin och Parton (1991) möjliga lösningar på problem som socialarbetare 
kan uppleva med nyhetsrapportering: utveckling av kontaktnät med nyckeljournalister, spridning av information "off the record", samt seminarier för journalister. På liknande sätt diskuterar Aldridge (1994) socialarbetares förhållande till massmedier med utgångspunkt i debatter i brittisk fackpress på 1980- och 1990-talen. Aldridge framhåller att socialarbetare inte förstår de kommersiella villkor och organisatoriska ramverk som journalister arbetare utifrån. Hon drar slutsatsen att socialtjänsten har behov av utbildning om massmedier och mer utvecklade kontaktnät med journalister.

På liknande sätt finns det endast ett fåtal studier av medierapportering om skolor, samt dessa organisationers mediehantering. En intervjustudie med rektorer inom den svenska gymnasieskolan beskriver hur marknadsföring och "image management" blivit en viktig del av skolpersonals arbete (Holm \& Lundström, 2011). Några empiriska studier av hur detta arbete tar sig uttryck finns dock inte att tillgå. Däremot visar Rönnberg et al. (2012) i en studie av Skolinspektionens mediehantering gentemot dagspress att myndigheten varit framgångsrik $i$ att nå massmedialt genomslag och använt massmedier för att nå fram med sin kritik av enskilda skolor.

Internationella studier av mediehantering inom polisväsendet visar sammantaget att polisen har en stark position i kontakten med journalister. Brott och polisarbete har högt nyhetsvärde. Företrädare för polisen är den källa som citeras mest i kriminaljournalistik och det finns många exempel på hur mediestra- tegier använts för att påverka mediernas skildringar av polisarbete (Chermak \& Weiss, 2005; Ericson et al., 1989; Lovell, 2001). Tidigare studier indikerar också att polisen och nyhetsmedierna generellt har ett nära samarbete vilket bägge parter kan dra nytta av. Polisen får gynnsam publicitet samtidigt som man kan komma i kontakt med allmänheten för att få hjälp med pågående brottsutredningar. För journalisternas del innebär samarbetet tillgång till trovärdiga källor på ett viktigt nyhetsområde. (Chermak \& Weiss, 2005; Ericson et al., 1989; Hall et al., 1978/1980).

Schlesinger och Tumber (1994) har i ett antal fallstudier studerat hur det brittiska polisväsendet försöker påverka medierapporteringen om kriminalitet. Författarna identifierar ett antal strategier, däribland systematisk mediebevakning för att snabbt kunna möta kritik och att bygga upp nätverk med journalister. Crandon och Dunne (1997) beskriver hur brittisk polis tillämpar tabloidpressens språkbruk i pressmeddelanden och ibland genomför massarresteringar på specifika dagar för att nå maximal massmedial uppmärksamhet. Mawby (1999) pekar samtidigt på att intresset för polisarbetet och dess synlighet leder till en större risk att misstag observeras av omgivningen.

I ett sällsynt försök att teoretisera över detta nya område har Thorbjornsrud et al. (2014) föreslagit en typologi för att fånga hur myndigheter anpassar sig till nyhetslogik. Syftet med denna modell är att problematisera spänningen mellan nyhetslogik och myndighetslogik. De lyfter fram fyra aspekter som särskilt centrala: nyhetsrytm, nyhetsformat, hur byrå- 


\section{Figur I.}

Mediehanteringens institutionella villkor

\begin{tabular}{|l|l|l|}
\hline \multicolumn{1}{|c|}{ Styrning } & \multicolumn{1}{|c|}{ Insyn } & \multicolumn{1}{c|}{ Omvärldsintresse } \\
\hline - Politik & $\bullet$ Verksamhetens synlighet & - Nyhetsvärde \\
- Profession & - Informationskontroll & - Intressenter och målgrupper \\
- Tillsyn och översyn & & Andra aktörer \\
\hline
\end{tabular}

krater ser på värdet av publicitet samt hur publicitet i förlängningen påverkar allokering av resurser och ansvar inom offentlig förvaltning. Deras modell är av stor betydelse för att förstå myndigheters relationer till massmedier. Vi har också influerats av den när vi har tagit fram vår teoretiska modell, särskilt vad gäller nyhetsvärde och möjligheter till informationskontroll.

\section{Institutionella villkor för mediehantering}

Allmänt sett ställs organisationer inom offentlig sektor inför höga krav på att kunna redogöra för sin verksamhet på ett genomskinligt sätt. Offentliga organisationer som socialtjänst och skola beskrivs ofta som särskilt beroende av sin organisatoriska och politiska kontext (Thorbjornsud et al., 2014). Detta beroende kommer sig av att stöd från allmänhet och politiker är särskilt viktigt för att säkerställa fortsatt finansiering (Hasenfeld, 2010). Med andra ord är denna typ av organisationer särskilt sårbar för vad som på engelska har kallats "reputational risk" (Power et al., 2009).

Inom offentlig sektor finns det en stor spännvidd av organisationer med olika mål, rättsliga ramverk och andra förutsättningar. Behovet av mediehan- tering och villkoren för hur den kan bedrivas varierar därför. Med utgångspunkt i empiriska studier och de initiala teoretiska bidrag som finns i litteraturen har vi utvecklat en modell som beskriver institutionella villkor för mediehantering i offentliga organisationer (se till exempel Altheide \& Snow, 1979; Chermak \& Weiss, 2005; Reid och Misener, 2001; Thorbjornsrud et al., 2014). I detta sammanhang har vi tagit hänsyn till de berörda organisationstypernas specifika medierelationer, samt massmediers bevakning av offentliga organisationer. Modellen är primärt skapad för att analysera mer kvalitativa aspekter av mediehanteringen. Samtidigt menar vi att modellen även kan bidra med förståelse för skillnader mellan organisationstyper i den kvantitativa studie som här presenteras.

Vi har delat in de institutionella villkoren i tre kategorier. Styrning är uppdelad i fyra institutionella villkor: Politik avser i vilken utsträckning politiskt valda församlingar har inflytande över strategisk styrning, samt över konkreta myndighetsbeslut. Med profession avses graden av autonomi inom de olika professionerna. Former för till- och översyn sker på olika sätt och med varierande sanktionsmöjligheter när missgrepp identifieras. Konkurrens handlar om förekomsten 
av konkurrerande aktörer på den aktuella organisationens fält.

Den andra kategorin som vi valt att kalla för insyn omfattar två villkor. "Verksamhetens synlighet" avser i vilken grad organisationernas verksamheter är direkt observerbara för allmänheten. Villkoret "Informationskontroll" rör framför allt i vilken utsträckning organisationernas verksamheter påverkas av sekretessregler.

Vad gäller kategorin omvärldsintresse avser "Nyhetsvärde" vilken vikt massmedier fäster vid organisationens verksamhet. Nästa villkor berör vilka intressenter och primära målgrupper som organisationerna har att förhålla sig till. Villkoret "Andra aktörer" handlar om i vilken utsträckning det finns andra aktörer som är medialt aktiva inom samma område.

De tre organisationstyper vi studerar skiljer sig åt med avseende på institutionella villkor på ett sätt som kan förväntas få betydelse för mediehanteringen. Beträffande styrning är politikers direkta inblandning i operativ verksamhet och myndighetsbeslut störst inom socialtjänsten och minst inom polisen. Socialtjänstens verksamhet framstår också överlag som svårare att mäta och följa upp än de andra. Gymnasieskolan utmärker sig genom en hög grad av konkurrensutsättning, vilket inte är lika vanligt inom socialtjänstens och framför allt polisens områden. I fråga om insynsvillkor är socialtjänstens verksamhet rimligtvis minst synlig för allmänheten, $\mathrm{i}$ kontrast till polisen som ofta gör ingripanden i det offentliga rummet. Sekretess berör alla tre organisationer och griper in på olika sätt, men har störst påverkan på socialtjänstens mediehantering - till stor del på grund av verksamhetens ofta känsliga natur. När det gäller exempelvis förundersökningssekretess har polisen i jämförelse med de kommunala organisationstyperna något mjukare regler, då dessa enbart är i kraft medan ett ärende fortfarande utreds och dessutom enkelt kan hävas genom beslut från åklagare. Alla organisationstyperna omfattas av meddelarfrihet, dock gäller inte denna i friskolor och verksamhet som socialtjänsten lagt ut på entreprenad. Villkoret "Nyhetsvärde" hör till kategorin omvärldsintresse. Här sticker den dramatiska karaktären i polisens uppdrag ut, medan socialtjänstens ordinarie verksamhet torde ha ett lägre nyhetsvärde än skolans. Polisens arbete uppfattas överlag som intressant och relevant av allmänheten, medan de kommunala organisationerna primärt är intressanta för de grupper som mer direkt berörs av dem. Polisen kan sägas ha en tämligen vag målgrupp i form om allmänheten, skolan tydliga och breda målgrupper i form av föräldrar och elever, medan socialtjänstens klientgrupper är specifika för olika verksamhetsområden med varierande grad av allmänintresse.

I den följande analysen kommer vi mer utförligt att diskutera den betydelse skillnader i institutionella villkor kan ha för mediehanteringen.

\section{Metod}

Studien bygger på telefonenkäter riktade till de operativt ansvariga för massmediekontakter i ett urval av organisationer. Frågorna har ställts till den person som på 
daglig basis planerar och styr organisationens agerande i mediefrågor. I framställningen benämns dessa som pressansvariga. Urvalet av organisationer består av samtliga 21 länspolismyndigheter, samt ett stratifierat slumpmässigt urval av vardera 100 social- respektive skolförvaltningar från landets 290 kommuner. Vad gäller kommunerna stratifierades kommuntyperna utifrån "storstad", "större stad", "förortskommun" och "övrigt". Denna uppdelning används av Sveriges kommuner och landsting (SKL).

Operationaliseringen har inneburit vissa vägval. Både skol- och socialförvaltningar kan organiseras på olika sätt med olika grad av specialisering. ${ }^{2}$ För att uppnå så stor enhetlighet som möjligt har vi därför riktat in oss mot socialtjänstens Individ- och familjeomsorg (IFO) och gymnasieskolan i både urvalet och när vi ställt frågor. IFO har prioriterats då just detta område särskilt uppmärksammats i den tidigare forskningen, medan gymnasieskolan intresserat oss på grund av den högre konkurrensutsättning som där råder. I intervjuerna har dock informanterna till största del varit relevanta för hela socialtjänstens respektive skolans område.

En initial kontakt togs via epost och telefon, organisationerna fick själva avgöra vem som ansetts vara operativt ansvarig för massmediekontakterna. För länspolismyndigheterna besvarades enkäten i

2 I materialet finns två par av kommuner som samarbetar genom ett gymnasieförbund, vilket inneburit att samma person var ansvarig för massmediekontakterna i båda kommunerna. samtliga fall av en centralt placerad pressansvarig. Kommunenkäterna besvarades $i$ de flesta fall av förvaltningens högsta chef, men i några fall av en person med specifikt ansvar för kommunikation. Det externa bortfallet var för socialförvaltningarna tio procent, gymnasieförvaltningarna nio procent och för länspolismyndigheterna obefintligt. Det interna bortfallet är mindre än två procent i samtliga frågor som redovisas i artikeln, förutom Tabell 1, där det interna bortfallet för kommunerna är fem procent.

Datainsamlingen genomfördes under perioden februari-maj 2013. Enkäten innehöll både fasta svarsalternativ och öppna frågor. De forskare som genomförde enkätintervjuerna fyllde $\mathrm{i}$ formuläret under samtalen. Samtliga intervjuer spelades in, dels för ökad reliabilitet, dels för att i framtiden kunna göra noggrannare analyser av de öppna frågorna. Tidsåtgången varierade mellan 25 och 55 minuter. Valet att genomföra en telefonenkät innebar en möjlighet att förtydliga frågor för att undvika missförstånd vilket gjorde det möjligt att ifrågasätta validiteten i några av frågorna. Ett mindre antal frågor har av denna anledning uteslutits från analysen.

Utöver att frågorna utformats utifrån vår modell och befintlig forskning har projektdeltagarnas tidigare erfarenheter från de tre verksamheterna och mediernas arbetssätt varit en resurs. Stefan Sjöström och Jesper Enbom har varit ledamöter i socialnämnd respektive för- och grundskolenämnd; projektmedarbetaren Erik Borglund har tidigare arbetat som polis och Adam Öhman har en bakgrund 
Tabell I.

Förekomst av skriftliga riktlinjer för massmediekontakter (procent)

\begin{tabular}{|l|c|c|c|}
\hline \multirow{2}{*}{} & \multicolumn{3}{|c|}{ Organisationstyp } \\
\cline { 2 - 4 } & Polis & Skola & Socialtjänst \\
\hline Rikspolis/Kommuncentralt & 95 & 51 & 55 \\
Polismyndighet/Förvaltning & 5 & 0 & 2 \\
Både och & 0 & 23 & 20 \\
Nej & 0 & 26 & 22 \\
\hline
\end{tabular}

$\mathrm{P}=0,004$.

som journalist i press, radio och TV, såväl på lokal-som på riksnivå.

\section{Resultat och analys}

Resultaten presenteras i tre tematiska avsnitt - policy, personal och aktivitet - som tillsammans ger en helhetsbild av mediehanteringens huvudsakliga aspekter. Skillnader mellan organisationstyperna diskuteras med hjälp av den teoretiska modellen om institutionella villkor.

\section{Policy}

Riktlinjer för massmediekontakter, vilka föreskriver hur anställda bör agera i relation till massmedier, har en central funktion i många organisationers mediehantering (Fredriksson \& Pallas, 2013). Förekomsten av riktlinjer indikerar i vilken omfattning organisationerna har systematiserat och formulerat principer för sin mediehantering. 79 procent av organisationerna har någon form av skriftligt formulerade riktlinjer som avser kontakter med nyhetsmedier (antingen sådana som uteslutande behandlar mediefrågor, eller mer allmänt hållna kommunikationsdokument som i någon del anger hur organisationen ska agera i relation till massmedier).

Av Tabell 1 framgår att social- respektive skolförvaltningarna främst har riktlinjer på kommuncentral nivå, det vill säga sådana som vanligtvis är gemensamma för kommunens förvaltningar. Samtidigt har var femte socialförvaltning respektive skolförvaltning både en skriftlig kommuncentral policy och ett policydokument som är utarbetat specifikt för den egna förvaltningen. Polismyndigheterna har gemensamma riktlinjer för hela landet, medan lokala riktlinjer sällan förekommer.

En viktig aspekt av organisationers relationer till medier är hur de kommunicerar vid kriser (Coombs, 2007). Som framgår av tabell 2 har merparten av förvaltningarna rutiner/riktlinjer för massmedial krishantering (hantering av granskning men även medierelationer vid "verkliga" kriser, som störningar i lokaltrafiken eller vattenläckor). Samtliga polismyndigheter och en stor majoritet av de kommunala förvaltningarna har en sådan krisplan. Vanligtvis finns riktlinjerna centralt på kommunerna, men det förekommer att 
Tabell 2.

Förekomst av rutiner/riktlinjer för massmedial krishantering (procent)

\begin{tabular}{|l|c|c|c|}
\hline \multirow{2}{*}{} & \multicolumn{3}{|c|}{ Organisationstyp } \\
\cline { 2 - 4 } & Polis & Skola & Socialtjänst \\
\hline Rikspolis/Kommuncentralt & 43 & 55 & 57 \\
Polismyndighet/Förvaltning & 48 & 15 & 4 \\
Både och & 10 & 25 & 31 \\
Nej & 0 & 6 & 8 \\
\hline
\end{tabular}

$\mathrm{P}=0,000$.

förvaltningar har egna krisplaner. Det kan noteras att Rikspolisstyrelsen har en central policy för medie- och krishantering, men att många respondenter inte har angivit detta (RPS, 2008).

Respondenterna berättade även om rutinerna/riktlinjerna för massmedial krishantering kommit till användning. Kartläggningen visar att 58 procent av skolförvaltningarna och 57 procent av polismyndigheterna använt sina krisplaner, medan motsvarande siffra för socialförvaltningarna är 37 procent.

Trots att institutionella villkor kan se olika ut för de tre organisationstyperna är upprättande av riktlinjer för mediehantering ett viktigt inslag för alla. Detta torde återspegla den allmänna tendensen att offentliga organisationer blivit mer upptagna av mediehantering (Fredriksson \& Pallas, 2013). En skillnad att notera är att polisen undantagslöst har skriftliga riktlinjer för både mediehantering $\mathrm{i}$ allmänhet och krishantering. Vi tolkar detta som ett uttryck för att polisens verksamhet har högre nyhetsvärde och att verksamheten i mångt och mycket är inriktad på att hantera extraordinära händelser. En annan förklaring är sannolikt att polisen i stor utsträckning har anställda som har ett specialiserat ansvar för mediehantering (se Personalnedan).

\section{Personal}

Personalen är en uppenbart viktig resurs när det gäller mediehantering. Den stora majoriteten av socialförvaltningarna (88 procent) och skolförvaltningarna (81 procent) har inte någon anställd vars huvudsakliga uppgift är att arbeta med massmediekontakter. Inom polissektorn ser det helt annorlunda ut. Hela 71 procent av polismyndigheterna har minst en anställd med huvuduppgift att arbeta med mediefrågor. En femtedel av dem har till och med fler än tre anställda som främst jobbar med dessa frågor. På grund av bristande reliabilitet $i$ enkätfrågan om organisationernas budget är det svårt relatera antalet anställda till organisationernas totala resurser.

Flera studier har tidigare visat att pressansvariga ofta får strategiska funktioner genom att de inkluderas i styrelsesammanhang och får insyn i beslutsproces- 
Tabell 3.

Mellanchefers och baspersonals sammanlagda andel av organisationens massmediekontakter (procent)

\begin{tabular}{|l|c|c|c|}
\hline \multirow{2}{*}{} & \multicolumn{3}{|c|}{ Organisationstyp } \\
\cline { 2 - 4 } & Polis & Skola & Socialtjänst \\
\hline Det mesta & 38 & 10 & 3 \\
Mer än hälften & 33 & 44 & 18 \\
Mindre än hälften & 24 & 33 & 37 \\
Mycket liten & 5 & 12 & 42 \\
\hline
\end{tabular}

$\mathrm{P}=0,000$

ser (Enbom, 2009; Larsson, 2005). Vår kartläggning visar att den som har operativt ansvar för massmediekontakter åtminstone emellanåt deltar i ledningsgruppsmöten i 98 procent av organisationerna. I 89 procent av socialförvaltningarna, 87 procent av skolförvaltningarna och 81 procent av polismyndigheterna sker detta deltagande regelbundet. Även om vi saknar empiriskt underlag för att närmare beskriva betydelsen av de pressansvarigas positioner i detta avseende är det rimligt att anta att många av dem har strategiska funktioner. När det gäller de kommunala förvaltningarna kan de pressansvarigas deltagande i ledningsgruppsmöten till stor del förklaras av det faktum att de ofta är förvaltningschefer. Inte desto mindre visar dessa mönster att det ofta finns en organisatorisk koppling mellan ledningen och arbetet med medierelationer sett över organisationstyperna. Liknande mönster uppträder i pressansvarigas deltagande i möten med den politiska ledningen, med skillnaden att polisen här avviker från de andra. I 82 procent av skolförvaltningarna och 80 procent av socialförvaltningarna deltar den pressansvariga som regel i möten med den politiska ledningen, att jämföra med i knappt hälften av polismyndigheterna. Fjorton procent av pressansvariga inom polisen deltar aldrig i denna form av möten. Motsvarande siffra för skol- och socialförvaltningar är tre respektive två procent.

Vem som ges möjlighet eller tillåts yttra sig speglar hur noggrant en organisation kan kontrollera informationsflöden. Det finns tydliga skillnader mellan organisationstyperna i fråga om hur stor andel av massmediekontakterna som inte sköts av högsta chef och ledningsgrupp utan av mellanchefer och baspersonal. Det sistnämnda kan inkludera exempelvis poliser på fältet, lärare, socialsekreterare och hemtjänstpersonal.

Som framgår av Tabell 3 står mellanchefer och baspersonal för det mesta eller mer än hälften av massmediekontakterna i drygt två tredjedelar av polismyndigheterna. Endast en respondent inom polisen uppger att dessa personalgrupper hanterar en mycket liten del av 
Tabell 4.

Förekomst av kritik eller läckor av sekretessbelagd information till massmedier (procent)

\begin{tabular}{|l|c|c|c|}
\hline & Polis & Skola & Socialtjänst \\
\hline $\begin{array}{l}\text { Anställda kontaktar massmedier för att delge } \\
\text { kritik }(\mathrm{p}=0,159)\end{array}$ & & & \\
$>10$ ggr/år & 15 & 6 & 4 \\
$<10$ ggr/år & 75 & 63 & 62 \\
Aldrig & 10 & 31 & 34 \\
\hline Anställda delger sekretessbelagd information till & & & \\
massmedier ( $\mathrm{p}=0,000)$ & & & \\
$>10$ ggr/år & 16 & 0 & 6 \\
$<10$ ggr/år & 74 & 92 & 94 \\
Aldrig & 10 & 92 & \\
\hline
\end{tabular}

organisationens massmediekontakter. Även vid skolförvaltningarna står mellanchefer och baspersonal för en relativt stor del av massmediekontakterna: i mer än hälften av skolorganisationerna håller dessa kategorier i merparten av kontakterna. I detta hänseende framträder skillnader i jämförelse med socialförvaltningarna, i vilka mellanchefer och baspersonal står för en betydligt mindre del. I mer än en tredjedel av socialförvaltningarna bidrar mellanchefer och baspersonal med en mycket liten del av massmediekontakterna.

Meddelarfriheten möjliggör för anställda inom offentlig sektor att påtala och slå larm om korruption och andra oegentligheter inom verksamheten. Samtidigt kan så kallade "läckor" av information komplicera mediehantering, i så måtto att de versioner som organisationen själv vill förmedla utmanas (Ericson et al., 1989; Lovell, 2001; Manning, 2001).
Enligt respondenternas bedömningar är det betydligt vanligare med läckor eller kritik inom polismyndigheterna, där nio av tio varje år har anställda som kritiserar den egna organisationen i massmedier. Likaså delger anställda på polismyndigheter betydligt oftare sekretesskyddad information från den egna organisationen än personal på skol- respektive socialförvaltningar. Endast två respondenter inom polissektorn uppger att det aldrig förekommer läckor av sekretesskyddat material.

Utbildning i mediehantering - ofta benämnt medieträning - förekommer frekvent $i$ alla tre organisationstyper. Sammantaget har 68 procent av organisationerna någon gång genomfört utbildning i massmediekontakter. Det finns dock skillnader mellan organisationstyperna.

Som framgår av tabell 5 är utbildning i massmediekontakter betydligt vanligare inom polismyndigheterna än inom skol- och socialförvaltningarna. Sett till 
Tabell 5.

Andel anställda som erhällit utbildning i massmediekontakter (procent)

\begin{tabular}{|l|c|c|c|}
\hline \multirow{2}{*}{} & \multicolumn{3}{|c|}{ Organisationstyp } \\
\cline { 2 - 4 } & Polis & Skola & Socialtjänst \\
\hline Genomfört & 95 & 65 & 67 \\
Ej genomfört & 5 & 35 & 33 \\
\hline
\end{tabular}

$\mathrm{P}=0,022$

vilka personalgrupper som får utbildning i massmediekontakter är den genomgående linjen att högsta chefen alltid får sådan träning (se tabell 6). Samtliga polismyndigheter utom en har haft medieträning. I alla dessa fall har högsta chef och ledningsgrupp utbildats. Men nästan nio av tio polismyndigheter har också utbildat mellanchefer, att jämföra med ungefär fyra av fem skolförvaltningar och knappt hälften av socialförvaltningarna. Men den stora skillnaden framträder beträffande baspersonal. Nästan hälften av polismyndigheterna har utbildat baspersonal i massmediekontakter, medan motsvarande andelar hos skol- och socialförvaltningarna är betydligt lägre.

Det vanligaste är att organisationerna köper medieträning från externa företag, det gäller för 83 procent av de skolförvaltningar, 82 procent av de socialförvaltningar och 74 procent av de polismyndigheter som genomfört medieträning. I jämförelse med kommunerna har relativt många polismyndigheter på egen hand anordnat ytterligare medieträning inom ramen för den egna organisationen. Nästan två tredjedelar av de polismyndigheter som har haft medieträning har ordnat sådan i egen regi. Endast 14 procent av skolförvaltningarna och fem pro- cent av socialförvaltningarna har anordnat medieträning på egen hand.

Respondenterna fick också ange innehåll i medieträning. Överlag är övningar i intervjuteknik vanligast, vilket genomförts inom samtliga polismyndigheter. Polismyndigheterna har också oftare haft genomgångar av redaktionernas nyhetsvärdering, villkor och arbetssätt, medan skol- och socialförvaltningar oftare har anordnat övningar i hur man skriver pressmeddelanden. Undervisning om roll- och ansvarsfördelning vid massmediekontakter förekommer i likartad omfattning mellan organisationstyperna.

För att sammanfatta övergripande likheter mellan organisationstyperna med avseende på personal kan vi först konstatera att de pressansvariga i regel sitter i ledningsgrupp eller motsvarande. Detta kan ses som en indikation på den betydelse som organisationerna tillmäter arbetet med massmediekontakter. Denna organisering medför bland annat att den ansvariga får insyn $\mathrm{i}$ beslutsprocesser och därigenom kan ge journalister mer utförlig information (Enbom, 2009; Manning, 1998). Den stora utbredningen av medieträning som vi finner ligger i linje med tidigare forskning om både privat 


\section{Tabell 6.}

Medieträning i olikapersonalgrupper (procent)*

\begin{tabular}{|l|c|c|c|}
\hline \multirow{2}{*}{} & \multicolumn{3}{|c|}{ Organisationstyp } \\
\cline { 2 - 4 } & Polis & Skola & Socialtjänst \\
\hline Högsta chef & 100 & 100 & 97 \\
Ledningsgrupp & 100 & 90 & 87 \\
Mellanchefer & 90 & 80 & 49 \\
Baspersonal & 47 & 9 & 3 \\
\hline
\end{tabular}

$\mathrm{P}=0,000$

* Avser de organisationer som har genomfört medieträning

och offentlig sektor (Davis, 2002/2009; Manning, 2001). En annan övergripande likhet mellan organisationstyperna gäller hur och varifrån de hämtar ny kunskap till sina utbildningar i massmediekontakter. Oberoende av ansvars- och arbetsområde är det vanligast att organisationerna anlitar externa företag för att utbilda personal i dessa frågor.

I resultaten finns också påtagliga skillnader mellan organisationstyperna. En viktig övergripande sådan är att polisen skiljer sig från skola och socialtjänst. Till exempel är antalet anställda med massmediekontakter som huvudsaklig arbetsuppgift större inom polisen. Ett institutionellt villkor som delvis kan förklara denna skillnad är det högre nyhetsvärde som brott har, liksom att polisen är mer beroende än de kommunala organisationerna av att få hjälp av allmänheten.

Polismyndigheternas pressansvariga deltar inte lika ofta i möten med de politiska ledningarna som sina motsvarigheter inom de kommunala förvaltningarna. Detta förhållande kan förklaras av styrningsvillkoret att den politiska ledningen där inte har samma direkta inflytande över operativ verksamhet som i med de kommunala förvaltningarna. En nog så betydelsefull orsak är också att de pressansvariga på skol- och socialförvaltningarna oftast är förvaltningschefer som per automatik deltar i alla nämndssammanträden.

Vår kartläggning visar att mellanchefer och baspersonal står för en stor del av massmediekontakterna inom polisen. En viktig anledning till detta finns i polismyndigheternas organisation. Länsmyndigheterna har delegerat ansvaret nedåt, till exempel till vakthavande befäl, i större utsträckning än framför allt socialförvaltningarna. Andra faktorer är att polisens arbete till stor del sker på allmän plats, särskilt $i$ jämförelse med socialförvaltningar, samt att enskilda poliser ofta blir kontaktade av reportrar (till exempel på brottsplatser) Mawby, 1999.

Enkätundersökningen visar vidare att det finns flera olika uttryck för informationsspridning som sker utanför de officiella kommunikationsfunktionerna från renodlad kritik av verksamheter till "läckor" av sekretesskyddat material. Det faktum att en större andel mellanchefer 
Tabell 7.

Förekomst av olika metoder för massmediekontakter (procent)

\begin{tabular}{|c|c|c|c|}
\hline & Polis & Skola & Socialtjänst \\
\hline \multicolumn{4}{|c|}{ Presskonferenser/pressträffar $(\mathrm{p}=0,002)$} \\
\hline > $3 \mathrm{ggr} / \mathrm{vecka}$ & 10 & 0 & 0 \\
\hline > 5 ggr/månad & 0 & 0 & । \\
\hline > 10 ggr/år & 29 & 23 & 28 \\
\hline < 10 ggr/år & 62 & 50 & 50 \\
\hline Aldrig & 0 & 27 & 21 \\
\hline \multicolumn{4}{|c|}{$\begin{array}{l}\text { Pressmeddelanden } \\
(p=0,000)\end{array}$} \\
\hline > 3 ggr/vecka & 10 & 0 & 0 \\
\hline > 5 ggr/månad & 52 & 11 & । \\
\hline > 10 ggr/år & 24 & 38 & 22 \\
\hline$<10$ ggr/år & 14 & 46 & 60 \\
\hline Aldrig & 0 & 6 & 17 \\
\hline \multicolumn{4}{|l|}{$\begin{array}{l}\text { Direktkontakter } \\
(p=0,000)\end{array}$} \\
\hline > 3 ggr/vecka & 33 & 2 & 3 \\
\hline > 5 ggr/månad & 24 & 19 & 10 \\
\hline > 10 ggr/år & 24 & 50 & 42 \\
\hline$<10$ ggr/år & 14 & 27 & 44 \\
\hline Aldrig & 4.8 & 2 & । \\
\hline \multicolumn{4}{|c|}{$\begin{array}{l}\text { Debattartiklarlinsändare } \\
(p=0,00 \mathrm{I})\end{array}$} \\
\hline > 3 ggr/vecka & 0 & 0 & 0 \\
\hline > 5 ggr/månad & 5 & 1 & 1 \\
\hline > 10 ggr/år & 19 & 10 & 3 \\
\hline < 10 ggr/år & 71 & 48 & 41 \\
\hline Aldrig & 5 & 40 & 55 \\
\hline
\end{tabular}


och baspersonal inom polisen har kontakter med journalister skapar fler kontaktytor, vilket kan förklara att poliser oftare läcker material eller använder massmedier för kritik. Den närmast totala frånvaron av spridning av sekretessbelagd information inom skolförvaltningar och i synnerhet socialförvaltningar kan bero på att sekretessen inom dessa områden ofta gäller uppgifter om enskilda personer som uppfattas som utsatta. Inom polisens område förekommer vid sidan av sekretess med hänsyn till enskilda personer även sekretess under pågående förundersökningar.

Även om de kommunala förvaltningarna liknar varandra i många avseenden, finns det också skillnader dem emellan. Mellanchefer och baspersonal inom gymnasieskolan har mer massmediekontakter än motsvarande grupper inom socialtjänsten. Detta kan delvis bero på rektorernas roll. De har ett tydligare ansvar för strategiska frågor än till exempel enhetschefer inom individoch familjeomsorg. Här torde även hänsyn till sekretess spela in, då dessa frågor oftare aktualiseras inom socialtjänsten. Den ökade marknadsorienteringen inom skolans område ökar sannolikt incitamenten för rektorer, men även till viss del för lärare, att förhålla sig aktivt till mediefrågor. Detta förhållande överensstämmer med mönster i tidigare forskning (Erixon Arreman \& Holm, 2011; Lundström \& Holm, 2011). Att mellanchefer inom skolsektorn ges medieträning i relativt stor utsträckning kan i detta sammanhang inte betraktas som en tillfällighet.

\section{Aktivitet}

En del av det empiriska materialet berör organisationernas aktivitet i fråga om massmediekontakter. När vi undersökt ett antal vedertagna metoder för mediehantering är det tydligt att polismyndigheterna är mer aktiva än skoloch socialförvaltningarna (se Tabell 7).

Samtliga polismyndigheter anordnar presskonferenser någon gång per år, medan en betydande minoritet av skoloch socialförvaltningar aldrig anordnar presskonferenser. Polisen skickar också betydligt oftare pressmeddelanden till redaktioner än de kommunala förvaltningarna, bland vilka skolorna är något mer aktiva. Mer än hälften av polismyndigheterna skickar ut pressmeddelande fem gånger i månaden eller oftare - endast en socialförvaltning ligger på samma nivå. Med direktkontakter avses de övriga kontakter som anställda tar med journalister Kategorin baseras på uppskattningar från enbart en person i organisationen, och bör därför betraktas med viss försiktighet. Polisen har även på denna punkt en framträdande position, vilket delvis ligger i linje med tidigare forskning, som visar att polisen har närmast rutinmässiga kontakter med journalister (se till exempel Schlesinger \& Tumber, 1994). Vidare har skolförvaltningarna fler direktkontakter med journalister än socialförvaltningarna. Liknande mönster föreligger också vad gäller debattartiklar/insändare.

Nästan samtliga (97 procent) organisationer publicerar notiser, det vill säga kortare texter med nyheter om organisationen, på sin hemsida med avsikt att (helt 
Tabell 8.

Upplevelse av organisationens relation till journalister (procent)

\begin{tabular}{|l|c|c|c|}
\hline \multirow{2}{*}{} & \multicolumn{3}{|c|}{ Organisationstyp } \\
\cline { 2 - 4 } & Polis & Skola & Socialtjänst \\
\hline Utmärkt & 57 & 17 & 12 \\
God & 43 & 61 & 54 \\
Neutral & 0 & 20 & 33 \\
Dålig & 0 & 2 & 1 \\
\hline
\end{tabular}

$\mathrm{P}=0,000$.

eller delvis) nå journalister. Denna kategori har dock vissa svagheter vad gäller validitet och bör beaktas med försiktighet. Likväl visar resultaten på intressanta tendenser. 81 procent av polismyndigheterna publicerar notiser på hemsidan tre gånger i veckan eller oftare med avsikt att nå journalister, och 14 procent av dem använder hemsidan mer än fem gånger i månaden. Ingen socialförvaltning och endast nio procent av skolförvaltningarna lägger ut notiser på hemsidan i detta syfte flera gånger i veckan. Vidare publicerar 30 procent av skolförvaltningarna och 13 procent av socialförvaltningarna notiser på hemsidan fem gånger $\mathrm{i}$ månaden eller oftare. Polismyndigheterna är följaktligen mer aktiva även på denna punkt, medan skolförvaltningarnas aktivitet är mer påtaglig än socialförvaltningarnas.

Mot bakgrund av organisationernas ansträngningar att påverka massmediernas rapportering är det intressant att veta hur respondenterna upplever och beskriver organisationens relation till journalister. Tabell 8 nedan visar att fler polismyndigheter än skol- och socialförvaltningar upplever att de har en utmärkt relation till journalister. Ingen polismyndighet uppger att den har en neutral eller dålig relation till journalister.

Det finns också en viss skillnad mellan skol- och socialförvaltningar där de förstnämnda är något mer nöjda med sina relationer till journalister.

En annan indikation på hur pass utvecklade relationer en organisation har till massmedier är hur ofta deras ansträngningar att förse journalister med material leder till publicitet. Samtliga polismyndigheter uppger att deras agerande leder till publicitet varje vecka. Ett sådant utfall är tvärtom mycket ovanligt i de andra organisationstyperna, där blott 12 procent av skol- och fem procent av socialförvaltningarna får publicitet på veckobasis.

Sammanfattningsvis konstaterar vi att i princip samtliga undersökta organisationer arbetar aktivt för att nå massmedialt genomslag. Detta visar sig i synnerhet i direktkontakter med journalister och utläggning av notiser på hemsidan, men en stor majoritet av organisationerna skickar också ut pressmeddelanden och anordnar presskonferenser. 
Även om det förekommer likheter i det empiriska materialet är skillnaderna mellan organisationstyperna återigen mer påtagliga. Polisen använder överlag presskonferenser, pressmeddelanden och direktkontakter betydligt oftare än de kommunala förvaltningarna, vilket ännu en gång illustrerar hur pass utvecklat polisens arbete i mediefrågor är. Polismyndigheternas agerande för att förse journalister med material leder också till publicitet betydligt oftare än de kommunala förvaltningarnas ansträngningar på detta område. Ett villkor som är betydelsefullt både för hur aktiva organisationer är i relation till massmedier och i vilken utsträckning de får publicitet är organisationsfältets nyhetsvärde. Polismyndigheter utgör pålitliga källor för nyhetsuppslag. Redaktioner har ofta reportrar som skriver om brott specifikt, medan det inte är lika vanligt med reportrar som är specialiserade på socialt arbete eller utbildning. När nyhetsredaktioner har reportrar med specifika bevakningsområden ökar sannolikheten att händelser inom dessa områden röner massmedial uppmärksamhet. För polisen får relationerna med massmedier således mer karaktären av ett kontinuerligt utbyte, medan socialförvaltningar och skolförvaltningar inte har lika väl utvecklade relationer.

Ett annat villkor som delvis kan förklara polismyndigheternas högre aktivitet är organisationens intressenter och primära målgrupper. Polisen har som ambition att nå en bredare allmänhet för att nå sina mål, medan de kommunala förvaltningarnas primära målgrupper är mer specifika.
Polismyndigheterna upplever också i större utsträckning än de kommunala förvaltningarna att de har en utmärkt relation till journalister. Detta kan delvis bero på att de får större genomslag i massmedier, vilket i viss mån är kopplat till frågor om organisationsfältets nyhetsvärde, men också att de har en organisation som präglas av professionalitet i fråga om medierelationer.

Om det mest framträdande resultatet av studien är skillnaden mellan polismyndigheterna och de kommunala förvaltningarna bör det ändå noteras vissa skillnader mellan de sistnämnda. En sådan tydlig skillnad gäller metoder. Skolförvaltningarna är på flera punkter mer aktiva än socialförvaltningarna: de skickar oftare pressmeddelanden till redaktioner, de har oftare direktkontakter med journalister och skriver oftare debattartiklar/insändare. Det faktum att skolorganisationerna är mer aktiva än socialförvaltningarna i dessa avseenden bör delvis förstås mot bakgrund av den konkurrens som är särskilt påfallande inom utbildningsområdet. När gymnasieskolor ständigt måste attrahera elever så kan marknadsföring, men även mediehantering, utgöra en viktig del för att uppnå detta. Skolorganisationernas mer aktiva arbete med medierelationer kan också vara en viktig förklaring till att de får mer publicitet än socialförvaltningarna.

\section{Sammanfattande diskussion}

Vad finns då att säga efter denna första nationella kartläggning om mediehantering i offentliga organisationer? För det första konstaterar vi att med undantag 
för ett fåtal små kommuner, bedriver alla undersökta organisationer ett systematiskt arbete med mediehantering. De flesta organisationerna har en policy för massmediekontakter och det är överlag vanligt med medieträning. Omkring hälften av organisationerna når framgång $\mathrm{i}$ publicering efter egna initiativ, åtminstone någon gång i månaden Två tredjedelar har direktkontakter med massmedier minst tio gånger per år. Fyra av fem arrangerar presskonferenser och nio av tio skickar ut pressmeddelanden. Omfattningen och inriktningen på arbetet varierar samtidigt avsevärt mellan organisationstyper. Här sticker framför allt polisen ut i jämförelse med de kommunala förvaltningarna med en långt mer utvecklad mediehantering, vilket visar sig i nästan alla undersökningsvariabler (jfr Chermak \& Weiss 2005; Lovell, 2001). Det finns även vissa skillnader mellan de kommunala organisationerna. Skolförvaltningarna är mer aktiva i att agera för att nå publicitet och får också betydligt större genomslag.

Utifrån det missnöje inför socialtjänstens relation till massmedier som ventilerats bland såväl forskare som praktiker (se t ex Franklin \& Parton, 1991; Brunnberg, 2001) är det intressant att våra resultat pekar i en delvis annan riktning. Endast ett försvinnande litet antal socialförvaltningar är missnöjda med sin relation till massmedier. Överlag är dock företrädare för socialförvaltningarna mindre nöjda än deras motsvarigheter inom gymnasieskolan och i synnerhet inom polisen.

Vi har haft ambitionen att tillämpa en ny modell om institutionella villkor för mediehantering för att tolka utfallet. Flera av de skillnader i villkor som vi har postulerat $\mathrm{i}$ vår teoretiska modell sammanfaller med den empiriska variationen i materialet: polisen skiljer sig från skola och socialtjänst både $\mathrm{i}$ den teoretiska modellen och i det empiriska utfallet. Frågan är då vilka institutionella villkor som slår igenom mest. Vår tolkning är att det framför allt är villkor relaterade till omvärldsintresse som bidrar med förståelse för polisens mer omfattande arbete med mediehantering i jämförelse med de andra organisationstyperna. Dess verksamhet röner ett större nyhetsvärde och har i stor utsträckning allmänheten som målgrupp. Även villkor för insyn kan verka i samma riktning, både på grund av polisverksamhetens synlighet och att sekretess i mindre grad blir hinder att delge information till journalister. Beträffande villkor relaterade till styrning kan de regelbundna jämförelser som görs inom skolan i form av betyg och nationella prov skapa behov av mediehantering. På samma sätt kan den högre konkurrensutsättningen medföra att skolförvaltningar ser större behov av mediehantering än socialförvaltningar. En spännande fråga för framtida forskning är hur privata aktörer inom skattefinansierad verksamhet arbetar med mediehantering. Detta är inte minst relevant med tanke på att dessa organisationer inte är tvungna att ta hänsyn till offentlighetsprincipen och meddelarfriheten.

Vilka reflektioner kan då göras beträffande valet av metod och studiens genomförande? Inledningsvis är det viktigt att betona att de data som har analyserats 
inte möjliggör direkta kopplingar mellan utfall och villkor. Våra tolkningar är teoretiska. En av studiens styrkor är dess goda representativitet. En starkt bidragande orsak till den höga svarsfrekvensen är att vi genomförde undersökningen i form av en telefonenkät i stället för en postenkät. Validiteten är dock en aning osäker i vissa av enkätfrågorna. Exempelvis bör frågan om hur ofta organisationerna publicerar notiser på hemsidan i syfte att nå journalister betraktas med viss försiktighet. Det fanns i regel ingen tydlig åtskillnad mellan vilket material som var specifikt avsett för journalister och vilket som riktade sig till en bredare allmänhet.

Fastän materialet inte tillåter generella slutsatser om andra offentliga organisationer belyser studien en rad aspekter som är relevanta även i vidare perspektiv. Den modell vi föreslagit bör vara möjlig att tillämpa på fler organisationstyper och andra sorters data. Den mest omedelbara relevansen för modellen bör dock vara att använda den för att i kvalitativa studier specificera hur institutionella villkor inverkar på offentliga organisationers mediehantering. 


\section{Referenser}

Aldridge, M. (1990). Social-work and the news media - a hopeless case. British Journal of Social Work, 20(6), s 611-625.

Aldridge, M. (1994). Making social work news. New York: Routledge.

Allern, S. (1997). Nair kildene byr opp til dans: søkelys på PR-byråene og journalistikken. Oslo:Pax.

Altheide, D. L., \& Snow, R. P. (1979). Media logic. Beverly Hills: Sage.

Andersson, G., \& Lundström, T. (2004). Socialarbetare om massmedia. Nordisk sosialt arbeid, 24(1), s 2-18.

Ayre, P. (2001). Child protection and the media: Lessons from the last three decades. British Journal of Social Work, 31(6), s 887-901. doi: 10.1093/bjsw/31.6.887

Benoit, W. L. (1997). Image repair discourse and crisis communication. Public Relations Review, 23(2), s 177-186.

Brunnberg, E. (2001). Media och socialt arbete. En explorativ studie av mediarapporteringen som påverkansfaktor inom socialtjänsten i Sverige och England. Nordicom Information. 23(2), s 31-44.

Chermak, S., \& Weiss, A. (2005). Maintaining legitimacy using external communication strategies: An analysis of police-media relations. Journal of Criminal Justice, 33(5), s 501512.

Coombs, W. T. (2007). Ongoing crisis communication: planning, managing, and responding (2nd ed.) Los Angeles; London:SAGE.

Crandon, G. L., \& Dunne, S. (1997). Symbiosis or vassalage? The media and the law enforcers - the case of Avon and Somerset police. Policing and Society: An International Journal of Research and Policy, 8(1), s 77-91.

Davis, A. (2002/2009). Public relations democracy. Manchester: Manchester University Press.

Enbom, J. (2009). Facket $i$ det medialiserade samhället: en studie av LO:s och medlemsförbun- dens tillämpning av news management. Umeå universitet:Umeå.

Ericson, R. V., Baranek, P. M. \& Chan, J. B. L. (1989). Negotiating control: A study of news sources. Milton Keynes: Open University Press.

Erixon Arreman, I. \& Holm, A. (2011). Privatisation of public education? The emergence of independent upper secondary schools in Sweden. Journal of Education Policy. 26(2), s 225-243.

Ewen, S. (1996). PR! A social history of spin. New York: Basic Books.

Forsberg, B. (2011). Öppenhet varar längst. Vad gör socialtjänsten när drevet går? Akademikern, 2011-12-06.

Franklin, B. (1989). Wimps and bullies: Press reporting of child abuse. In P. Carter, T. Jeffs \& M. Smith (Eds.), Social work and social welfare yearbook. Vol. 1, pp. 1-14. Milton Keynes: Open University Press.

Franklin, B., \& Parton, N. (Eds.). (1991). Social work, the media and public relations. London: Routledge.

Fredriksson, M., \& Pallas, J. (2013). Med synlighet som ledstjärna: En analys av vilka principer som styr kommunikationsarbetet $i$ nationella förvaltningsmyndigheter. Division of Media and Communication Science Research. Report 2013:1. Uppsala: Uppsala University.

Galtung, J., \& Ruge, M. (1981). Structuring and selecting news. In S. Cohen \& J. Young (Eds.), The manufacture of news: social problems, deviance and the mass media. London: Sage.

Gregory, R. (2003). Accountability in modern government. In G. B. Peters \& J. Pierre (Eds.), Handbook of public administration. London: Sage.

Hall, S., Critcher, C., Jefferson, T., Clarke, J. \& Roberts, B. (1978/1980). Policing the crisis: Mugging, the state, and law and order. London: Macmillan.

Hasenfeld, Y. (2010). Human services as complex 
organizations (2. ed.). Los Angeles: Sage.

Ihlen, Ø., \& Thorbjørnsrud, K. (2014). Tears and Framing Contests: Public Organizations Countering Critical and Emotional Stories. International Journal of Strategic Communication, 8(1), 45-60.

Kearns, K. (2003). Accountability in a seamless economy. In G. B. Peters \& J. Pierre (Eds.), Handbook of public administration. London: Sage.

Larsson, L. (2005). Upplysning och propaganda: utvecklingen av svensk $P R$ och information. Lund:Studentlitteratur.

Lewin, L. (2007). Democratic accountability: why choice in politics is both possible and necessary. Cambridge, Mass.: Harvard University Press.

Lovell, J. S. (2001). Media power \& information control: A study of police organizations \& media relations. Newark, NJ: Rutgers University.

Lundahl, L. (2005). A matter of self-governance and control. European education, 37(1), $10-25$.

Lundström, U. \& Holm, A. (2011). Market competition in upper secondary Education: Perceived effects on teachers' work. Policy Futures in Education. 9(2), 193-205.

Manning, P. (1998). Spinning for labour: Trade unions and the new media environment Aldershot:Ashgate.

Manning, P. (2001). News and news Sources: A critical introduction. London: Sage.

Mawby, R. (1999). Visibility, transparency and police-media relations. Policing and Society: An International Journal of Research and Policy, 9(3), s 263-286.

Power, M. (2007). Organized uncertainty: designing a world of risk management. Oxford: Oxford University Press.

Power, M., Scheytt, T., Soin, K. \& Sahlin, K. (2009). Reputational risk as a logic of organizing in late modernity. Organization Studies, 30(2-3), s 301-324.
Reid, W. J. \& Misener, E. (2001). Social work in the press: a cross-national study. International Journal of Social Welfare, 10(3), s 194201.

Rikspolisstyrelsen (2008). Kommunikationspolicy och riktlinjer för kommunikation, KA-159-3051/09

Rothstein, H., Huber, M. \& Gaskell, G. (2006). A theory of risk colonization: the spiralling regulatory logics of societal and institutional risk. Economy and Society, 35(1), s 91-112.

Rönnberg, L., Lindgren, J. \& Segerholm, C. (2012). In the public eye: Swedish school inspection and local newspapers: Exploring the audit-media relationship. Journal of Education Policy. London: Routledge. DOI:1 0.1080/02680939.2012.701668.

Schillemans, T. (2012). Mediatization of public services. How organizations adapt to news media. Frankfurt a. M.: Peter Lang.

Schlesinger, P., \& Tumber, H. (1994). Reporting crime: the media politics of criminal justice. Oxford: Clarendon Press.

Scott, W. R. (2008). Institutions and organiza tions: ideas and interests (3. ed.). Thousand Oaks, Calif:: Sage.

Strömbäck, J. (2008). Four phases of mediatization: An analysis of the mediatization of politics. The International Journal of Press/ Politics, 13(3), s 228-246.

Tench, R., \& Yeomans, L. (2014). Exploring public relations (3. ed.). Harlow: Pearson Education.

Thorbjornsrud, K., Ustad Figenschou, T., \& Ihlen, Ø. (2014). Mediatization in public bureaucracies: A typology. Communications-The European Journal of Communication Research, 39(1), 3-22.

Tuchman, G. (1978). Making news. A study in the construction of reality. New York: The Free Press.

Wernick, A. (1991). Promotional culture: advertising, ideology and symbolic expression. London: Sage Publications. 


\section{Summary}

\section{Institutional conditions for news management A survey of social services, schools and the police}

In recent years, organizations within the public sector have become increasingly attentive to how they are perceived by the public. Professional news management is primarily associated with the private sector, where the rationale has been to maximize profit and market value. For organizations under democratic authority, the ultimate goals are different. The aim of this article is to describe and compare news management in three types of public sector organizations: school, police and social services. The three types of organizations are chosen because they appear different in some respects that might potentially affect news management.

The paper draws on data from a national survey of all 21 Swedish regional police authorities and a representative sample of municipal school $(\mathrm{n}=90)$ and social service administrations $(\mathrm{n}=91$ ) (attrition rate $<10 \%$ ). Data are analysed in terms of policies, personnel and activities.

With the exception of a couple of small municipalities, all organizations have a professional organization for and work systematically with media relations. The police authorities stand out in having implemented more developed strategies. The school administrations tend to be somewhat more active in their media relations than social services.

Differences between the types of organizations are discussed in terms of variation in institutional conditions for news management. The reason why the police stand out can be attributed to a higher newsworthiness, higher public visibility and less strict secrecy rules. We conclude by suggesting that conditions relating to public interests have the most impact on the formation of news management. 